\author{
Бондаренко С.А. \\ кандидат економічних наук, докторант \\ відділ економічного регулювання природокористування \\ Інститут проблем ринку та економіко-екологічних \\ досліджень НАН України Французький бульвар, 29, м. Одеса, Україна, 65044 \\ E-mail: lana.bond15@mail.ru \\ Селіхов С.B. \\ директор ТОВ «Селком ЛТД» \\ вул. Фонтанська дорога 12-Г, кв.49, м. Одеса, Україна, 65009 \\ E-mail: selser@ukr.net
}

\title{
ФОРМУВАННЯ СИСТЕМИ МОТИВАЦІЇ ПЕРСОНАЛУ ВИНОРОБНИХ ПІДПРИЄМСТВ НА ЗАСАДАХ ІННОВАЦІЙНИХ ТЕХНОЛОГІЙ
}

У статті розглядаються основні аспекти використання інноваційних технологій мотивації персоналу. Пропонується системний підхід до фрормування мотивації персоналу, виділено основні принципи формування ефективної системи мотивації персоналу з урахуванням особливостей виноробної галузі.

Ключові слова: мотивація персоналу, інноваційні технології мотивації персоналу, виноробні підприємства, система мотивації персоналу.

This work is licensed under a Creative Commons Attribution 4.0 International License http://creativecommons.org/licenses/by/4.0/

Постановка проблеми та її зв'язок з важливими науковими та практичними завданнями. Виноробство є однією з провідних стратегічних галузей харчової промисловості України. Для підприємств виноробної галузі України ключовими організаційними проблемами є відсутність сучасних систем і методів управління, орієнтація на підходи, які були ефективними в епоху індустріальної економіки. В умовах економіки знань основним показником конкурентоспроможності підприємства стає його інтелектуальний капітал, який є відображенням сумарної колективної інтелектуальної енергії підприємства. Система управлінням інтелектуальним капіталом має включати обов'язкове впровадження інноваційних технологій мотивації персоналу, які дозволяють економити всі види організаційних ресурсів, товарноматеріальних запасів, вивільняти фінанси, підвищувати життєздатність і ринкову стійкість підприємств, збільшувати їх прибутковість. Розуміння гостроти i актуальності проблеми мотивації персоналу, необхідність нових підходів до іï вирішення вимагає розробки науково обгрунтованих теоретичних та методологічних основ мотивації персоналу виноробних підприємств як складової соціально-трудових відносин.

Аналіз останніх досліджень і публікацій. Дослідженню проблем мотивації персоналу в теоретичному та практичному аспектах присвячено праці відомих вітчизняних та зарубіжних науковців, зокрема, А. Маслоу, Ф. Геруберга, Л. Портера, С. Бандура, Д. Богині, М. Генкіна, Г. Дмитренка, В. Жигалова, С. Занюка, А. Кібанова, А. Колота, Н. Мартиненка, В. Никифоренка, В. Онікієнка, М. Самікіної, В. Шинка- ренка та ін.

Окремі аспекти проблем щодо управління виноробними підприємствами знайшли відображення в роботах О.М. Гаркуши, Б.В. Буркинського, О.А. Іванилової, О.М. Литовченко, М.Х. Корецького, В.Т. Косюри, Р.В. Кружкової, І.А. Петренко, П. Саблука, В.О. Точиліна, О.В. Ульянченка, О.М. Шестопаль. Разом 3 тим, актуальними залишаються дослідження питань теоретичних, методологічних, методичних та практичних аспектів формування системи мотивації персоналу виноробних підприємств на засадах інноваційних технологій з урахуванням галузевої специфіки.

Формулювання цілей дослідження. Метою написання даної статті $€$ виявлення сучасних тенденцій та розробка основних аспектів формування системи мотивації персоналу виноробних підприємств на засадах інноваційних технологій.

Виклад основних результатів та їх обгрунтування. На сьогодні в Україні більшість працедавців використовують традиційні методи мотивації. Але вони є застарілими і не можуть в повній мірі виконувати мотиваційну функцію. Отже, потрібно вводити нові методи стимулювання працівників для підвищення їх продуктивності, зокрема, враховуючи міжнародний досвід.

Формування системи мотивації персоналу передбачає проведення роботи у двох напрямках. Поперше, це створення благоприємних умов праці, тобто забезпечення привабливості, престижності роботи, нормального психологічного клімату в колективі, особистісного розвитку працівника. По-друге, система безпосереднього впливу на виробничу поведінку 
співробітників. До цієї групи відносяться різні види матеріального і нематеріального заохочення працівників. У науковій літературі авторами була розроблена система мотивації персоналу, в основі якої лежить використання ряду управлінських технологій, які спираються на інноваційні підходи, характерні для новітньої епохи економіки знань [1].

Поняття «інновація» означає позитивне, прогресивне нововведення (ідею, діяльність, технологію або матеріальний об'єкт, який раніше не застосовувався організаційною системою) [2]. Категорія новизни відноситься до якісних характеристик змін, які носять істотний характер і супроводжуються змінами в образі діяльності і мислення [3]. Дослідження в області інноваційних технологій мотивації персоналу є актуальними як для практики менеджменту, так і для соціальної направленості управління.

Для виноробних підприємств виділяють наступні організаційно-управлінські інновації:

1) організаційні нововведення: креативні зміни організаційно-правових форм, на базі яких діє виноробне підприємство; розвиток процесу кооперації виноградарства і виноробства; нові форми технічного обслуговування і забезпечення ресурсами; підвищення рівня діяльності маркетингових служб підприємства, реструктуризація, запровадження новітніх комунікацій, створення ефективних каналів розподілу тощо;

2) управлінські нововведення: удосконалення організації і мотивації праці; впровадження прогресивних методик прогнозування, планування в умовах трансформації, методів ціноутворення та ін.;

3) удосконалення форм інноваційного розвитку виноробного підприємства [4].

Разом $з$ тим, інноваційний розвиток виноробного підприємства має носити соціальну направленість. У цьому сенсі, під соціальними інноваціями розуміється розвиток і впровадження нових ідей (продукції, послуг і моделей), які відповідають соціальним потребам. Це - процеси, що сприяють переходу на новий рівень розвитку всієї системи менеджменту підприємства, призводять до суттєвих та необоротних змін у взаємодії між членами колективу, направлені на задоволення їхніх нових духовних та інтелектуальних потреб. Для виноробних підприємств це $є$ : удосконалення умов праці, засобів соціальної інфраструктури, комунікацій; розвиток і підтримка нових соціальних цінностей; впровадження новітніх методів навчання та адаптації персоналу; удосконалення системи мотивації праці; фінансування розвитку об єктів соціальної інфраструктури власного підпорядкування; активізація інструментів соціальновідповідального маркетингу; нові методи оцінки умов праці; зміни внутрішньо колективних відносин тощо.

Однією з особливостей підприємств виноробної промисловості $є$ присутність в їх структурі сільськогосподарських та промислових підприємств: первинне виноробство представлене радгоспами та радгосп-заводами, вторинне - промисловими підприємствами - переробниками. Крім того, слід виділити, що підприємства є продавцями виноробної продукції. У зв'язку з цим можна провести розмежування підприємств за типом організації персоналу на підприємстві та виробничо-фінансового циклу на такі групи: виробники, переробники і продавці. Але особливістю більшості виноробних підприємств $\epsilon$ те, що вони поєднують в собі три групи. Отже, як для виробника, характерними є: низька ділова активність та низький рівень загруженості робітників на початку року, недостатність грошових коштів у період закупівлі предметів праці та пік грошового припливу у вереснілистопаді в результаті реалізації виробленої виноробної сировини. Для переробника характерні пік притоку грошових коштів у грудні-січні та дефіцит у вересні - листопаді. Як для продавця, притаманний більш високий рівень забезпеченості грошовими коштами у період зимових свят (грудень-січень) [5]. Удосконалення механізму мотивації персоналу, в тому числі і управлінського, має відбуватися на основі застосування заходів спрямованого стимулювання 3 врахуванням можливих мотивів конкретних груп персоналу підприємства. При цьому важливим $є$ застосування індивідуального підходу до мотивації з диференціацією персоналу не лише за категоріями, але і за етапом трудової кар'єри, з урахуванням специфіки та розміру підприємства. У табл. 1 проведено аналіз традиційних (епохи індустріальної економіки) і інноваційних (новітньої епохи економіки знань) підходів до мотивації персоналу, їх актуальність щодо специфіки виноробних підприємств.

Дані аналізу свідчать про неефективну систему мотивації праці на більшості вітчизняних виноробних підприємств через повне ігнорування інноваційних підходів. Це є зрозумілим, оскільки нинішній менеджмент на виноробних підприємствах не відповідає вимогам «економіки знань».

Таблиця 1

Традиційні та інноваційні підходи до мотивації персоналу з урахуванням специфіки виноробних підприємств *

\begin{tabular}{|c|c|c|c|}
\hline \multirow{2}{*}{$\begin{array}{c}\text { Технологія мотивації } \\
\text { персоналу }\end{array}$} & \multicolumn{2}{|c|}{ Характерні особливості за умови } & \multirow{2}{*}{$\begin{array}{c}\text { Щодо специфіки виноро- } \\
\text { бних підприємств }\end{array}$} \\
\hline & традиційного підходу & інноваційного підходу & \\
\hline $\begin{array}{l}\text { Мотивація персоналу } \\
\text { через застосування } \\
\text { технології визначення } \\
\text { цілей. }\end{array}$ & $\begin{array}{l}\text { Не передбачається ная- } \\
\text { вність прямого зв’язку } \\
\text { мотивації персоналу з } \\
\text { реалізацією цілей підп- } \\
\text { риємства. }\end{array}$ & $\begin{array}{l}\text { Актуальним є формування } \\
\text { мотиваційної системи, здат- } \\
\text { ної узгодити цілі працівни- } \\
\text { ків з цілями організації та } \\
\text { формувати систему цільової } \\
\text { мотивації. }\end{array}$ & $\begin{array}{l}\text { Характерним є традицій- } \\
\text { ний підхід. Інноваційний } \\
\text { підхід можливий за умови } \\
\text { наявності стратегії, цільо- } \\
\text { вої структури підприємст- } \\
\text { ва: місії, предметної цілі, } \\
\text { програми. }\end{array}$ \\
\hline
\end{tabular}


Продовження табл.1

\begin{tabular}{|c|c|c|c|}
\hline $\begin{array}{l}\text { Мотивація персоналу } \\
\text { через інноваційний } \\
\text { підхід до компенса- } \\
\text { ційних систем. }\end{array}$ & $\begin{array}{l}\text { Заробітна плата є моти- } \\
\text { ватором; їі збільшення і } \\
\text { розмір не залежить від } \\
\text { результатів і різниці між } \\
\text { ефективними і неефек- } \\
\text { тивними співробітника- } \\
\text { ми. }\end{array}$ & $\begin{array}{l}\text { Передбачає мотивацію через } \\
\text { відкриту систему оплати } \\
\text { праці, прив'язку компенса- } \\
\text { ційного пакета до індивідуа- } \\
\text { льного показниками ефекти- } \\
\text { вності. }\end{array}$ & $\begin{array}{l}\text { Характерним є традицій- } \\
\text { ний підхід. Використову- } \\
\text { ються сезонні працівники } \\
\text { низької кваліфікації з від- } \\
\text { повідним рівнем оплати. }\end{array}$ \\
\hline $\begin{array}{l}\text { Мотивація персоналу } \\
\text { через застосування } \\
\text { технології командоут- } \\
\text { ворення }\end{array}$ & $\begin{array}{l}\text { Результатами роботи } \\
\text { підприємства є сума } \\
\text { результатів роботи кож- } \\
\text { ного із співробітників, } \\
\text { (як правило, кількісних). }\end{array}$ & $\begin{array}{l}\text { Результати роботи підпри- } \\
\text { ємства безпосередньо зале- } \\
\text { жать від взаємодії між спів- } \\
\text { робітниками, від командної } \\
\text { роботи, а не тільки від інди- } \\
\text { відуальних досягнень. }\end{array}$ & $\begin{array}{l}\text { Характерним є традицій- } \\
\text { ний підхід. Висока частка } \\
\text { робітників у структурі } \\
\text { персоналу, нестача моло- } \\
\text { дих кадрів, що веде до } \\
\text { зменшення рівня іннова- } \\
\text { ційності виробництва і } \\
\text { управління. }\end{array}$ \\
\hline $\begin{array}{l}\text { Мотивація персоналу } \\
\text { через делегування } \\
\text { повноважень }\end{array}$ & $\begin{array}{l}\text { Передбачає часткове } \\
\text { або повне управління та } \\
\text { прийняття управлінсь- } \\
\text { ких рішень особою- } \\
\text { керівником підприємст- } \\
\text { ва (підрозділу). }\end{array}$ & $\begin{array}{l}\text { Включає залучення фахівців } \\
\text { до процесу розробки і при- } \\
\text { йняття управлінських рі- } \\
\text { шень, відповідальності, пе- } \\
\text { реговорів, дослідження, роз- } \\
\text { робки. }\end{array}$ & $\begin{array}{l}\text { Характерним є традицій- } \\
\text { ний підхід. Чисельність } \\
\text { робітників середнього віку } \\
\text { не зростає, збільшується } \\
\text { частка працівників стар- } \\
\text { шого віку, які повільно } \\
\text { адаптуються до управлін- } \\
\text { ських змін. }\end{array}$ \\
\hline $\begin{array}{l}\text { Мотивація персоналу } \\
\text { через застосування } \\
\text { інноваційних техно- } \\
\text { логій управління } \\
\text { кар'єрою }\end{array}$ & $\begin{array}{l}\text { Передбачає просування } \\
\text { співробітника вгору по } \\
\text { службових сходах орга- } \\
\text { нізації в рамках своєї } \\
\text { діяльності («вертикаль- } \\
\text { на кар’єра»). }\end{array}$ & $\begin{array}{l}\text { Передбачає просування } \\
\text { співробітника не тільки вго- } \\
\text { ру, а й з одного підрозділу } \\
\text { підприємства в інше («гори- } \\
\text { зонтальна», або «матрична», } \\
\text { кар’єра). }\end{array}$ & $\begin{array}{l}\text { Характерним є традицій- } \\
\text { ний підхід. Високий обо- } \\
\text { рот персоналу свідчить } \\
\text { про відсутність даної ін- } \\
\text { новаційної технологї мо- } \\
\text { тивації на підприємстві }\end{array}$ \\
\hline $\begin{array}{l}\text { Мотивація персоналу } \\
\text { через застосування } \\
\text { інноваційних техно- } \\
\text { логій підготовки і ро- } \\
\text { звитку персоналу }\end{array}$ & $\begin{array}{l}\text { Передбачає підвищення } \\
\text { кваліфікації, переквалі- } \\
\text { фікацію, відсутня взає- } \\
\text { мно узгодженість цілей } \\
\text { працівників і підприєм- } \\
\text { ства. }\end{array}$ & $\begin{array}{l}\text { Передбачає навчання на } \\
\text { протязі усього життя, отри- } \\
\text { мання нових компетенцій, } \\
\text { підготовка до нових посад у } \\
\text { відповідності до цілей підп- } \\
\text { риємства. }\end{array}$ & $\begin{array}{l}\text { Характерним є традицій- } \\
\text { ний підхід. Персонал пос- } \\
\text { тійно перебуває в русі, а } \\
\text { більшість робітників не } \\
\text { затримуються на робочо- } \\
\text { му місці довго. Висока } \\
\text { доля низькокваліфікова- } \\
\text { ного персоналу. }\end{array}$ \\
\hline $\begin{array}{l}\text { Мотивація персоналу } \\
\text { через застосування } \\
\text { інноваційних техно- } \\
\text { логій оцінки персона- } \\
\text { лу }\end{array}$ & $\begin{array}{l}\text { Об’єктом оцінки є інди- } \\
\text { відуальний співробіт- } \\
\text { ник. Методами оцінки є } \\
\text { переважно суб'єктивна } \\
\text { оцінка або психологічне } \\
\text { тестування. }\end{array}$ & $\begin{array}{l}\text { Головна мета системи оцін- } \\
\text { ки персоналу - аналіз відпо- } \\
\text { відності роботи цілям і на- } \\
\text { скільки спосіб їх досягнення } \\
\text { відповідає нормам етичного } \\
\text { кодексу. }\end{array}$ & $\begin{array}{l}\text { Характерним є традицій- } \\
\text { ний підхід. Не значні ви- } \\
\text { трати на оцінку персона- } \\
\text { лу; в основному оцінка } \\
\text { носить суб'єктивний ха- } \\
\text { рактер. }\end{array}$ \\
\hline $\begin{array}{l}\text { Мотивація персоналу } \\
\text { через інтеграцію в } \\
\text { корпоративну культу- } \\
\text { ру }\end{array}$ & $\begin{array}{l}\text { Не передбачається не- } \\
\text { обхідність цілеспрямо- } \\
\text { вано займатися форму- } \\
\text { ванням і управлінням } \\
\text { корпоративною культу- } \\
\text { рою в цілому. }\end{array}$ & $\begin{array}{l}\text { Передбачає цілеспрямоване } \\
\text { формування ідей, поглядів, } \\
\text { основоположних цінностей, } \\
\text { які поділяються членами } \\
\text { організації (shared values). }\end{array}$ & $\begin{array}{l}\text { Формується корпоративна } \\
\text { культура, що безумовно } \\
\text { створює стимул для якіс- } \\
\text { ної професійної діяльнос- } \\
\text { ті. }\end{array}$ \\
\hline
\end{tabular}

* розроблено авторами на основі [6], [7]

Для розуміння основних запитів важливо розуміти стан соціально-трудових відносин на виноробних підприємствах Одеської області. Моніторинг соціально-трудової сфери на виноробних підприємствах показав, що половина робочого персоналу неза- доволена умовами своєї праці (табл. 2). Так, 32\% опитаних працівників найбільшою проблемою вважають низький рівень заробітної плати. Проведений аналіз показав відсутність на виноробних підприємствах, як такої системи, що визначає рівень оплати праці. 
Результати моніторингу трудових відносин на виноробних підприємствах Одеської області*

\begin{tabular}{|c|c|c|}
\hline $\begin{array}{l}\text { Назвіть причину, чому Ви не задоволені } \\
\text { своєю роботою }\end{array}$ & Відповіді респондентів, \% & Відповіді респондентів, осіб \\
\hline Низька заробітна плата & 32 & 21 \\
\hline Несвоєчасна виплата зарплатні & 25 & 16 \\
\hline Незабезпеченість гідними умовами праці & 11 & 7 \\
\hline $\begin{array}{l}\text { Незабезпеченість необхідними засобами } \\
\text { праці }\end{array}$ & 8 & 5 \\
\hline Неповна оплата лікарняного та відпустки & 6 & 4 \\
\hline Несприятливий мікроклімат в колективі & 12 & 8 \\
\hline Важко відповісти & 6 & 4 \\
\hline Разом & 100 & 65 \\
\hline
\end{tabular}

Тобто система тарифних ставок, що існувала раніше, періодично піддавалася безсистемним змінам. Відсутня також система оцінки посад і професій по їх значимості з урахуванням персональних особливостей.

Крім того, є випадки несвоєчасних виплат заробітної плати $(25 \%)$, що, звичайно, є зовсім неприпустимим явищем і значним недоліком менеджменту підприємства. Незабезпеченість гідними умовами праці виділяють $11 \%$ від опитаних, а незабезпеченість необхідними засобами праці - 8\%. Це особливо негативно впливає на мотивацію розвитку управлінського персоналу. Виходом з цієї кризової ситуації є нарощування на виноробних підприємствах нематеріальних активів, адже світова економіка сьогодні - це нерозривний зв'язок наукових знань та їх комерційної реалізації. Тому не дивно, що проведений факторний аналіз показав значний вплив на мотивацію розвитку управлінського персоналу показника нематеріальних активів. На сьогодні на виноробних підприємствах Одеської області питома вага нематеріальних активів у балансах складає близько $2 \%$, а їх тенденції до збільшення є уривчастими. Проведений факторний аналіз дозволив виділити такі основні фактори впливу на мотивацію розвитку управлінського персоналу виноробних підприємств: соціально-економічний, техніко-технологічний, інноваційний.

3 метою виявлення основних мотиваційних потреб працівників для того, щоб налагодити систему мотивації та стимулювання, було проаналізовано мотиваційний потенціал виноробних підприємств Одеської області за допомогою методу кваліметричних оцінок. У ході цього аналізу було проведено спеціальне тестування, яке пройшли 65 працівників підприємств (респонденти обиралися вибірково). Рівень мотиваційного профілю опитаних працівників свідчить про часткову задоволеність потреб у цих працівників. На основі експертного опитування на виноробних підприємств Одеської області було виявлено, що найефективніший спосіб мотивації $є$ грошова винагорода $-67,2 \%$; за безкоштовне навчання та тренінги віддали свої голоси - 8,9 \% опитаних; похвалу від керівництва цінують - 6,6\% респондентів; персональні подарунки від компанії - 5,8 \%; штрафи та пока- рання змушують краще працювати - 4,7 \% працівників, а корпоративні свята - 4,1\%; найменше цінуються додаткові вихідні - так відповіли лише 2,7 \% опитаних.

Отже, проаналізувавши мотиваційний профіль виноробних підприємств Одеської області, можна зробити висновок про відсутність опрацьованої і актуальної системи мотивації на підприємствах 3 низьким ступенем стимулювання працівників.

Найбільшої ефективності мотивація має при системному підході. Системний підхід до мотивації персоналу заснований на всебічному врахуванні психологічних принципів мотиваційного процесу індивідуальної і групової діяльності, а також дієвих методів мотивації залучення, утримання і ефективної праці [8, 9]. Мотиваційна система - це один із найбільш дієвих інструментів управління, який складається із сукупності мотиваційних елементів, що дозволяють впливати на ефективність діяльності співробітників і підприємства в цілому. Налагоджена у відповідності зі стратегічними і тактичними орієнтирами виноробного підприємства, система мотивації дозволить менеджерам формувати необхідну поведінку співробітників, підвищити продуктивність, зацікавленість і лояльність персоналу. Система мотивації характеризує сукупність взаємопов'язаних заходів, які стимулюють окремого працівника або трудовий колектив у цілому щодо досягнення індивідуальних і спільних цілей діяльності підприємства. Мотиваційні системи формуються як комплекс різноманітних мотивів, який у свою чергу визначає стандарти поведінки. Система мотивації є динамічною, iіi складові постійно змінюються під впливом внутрішніх і зовнішніх факторів. Ефективний менеджмент повинен грунтуватися на поєднанні реальних цілей, життєвих цінностей і установок, очікувань і потреб працівника 3 цілями організації. Людина яка розділяє цілі й усвідомлює цінності своєї організації, здатна визначати для себе завдання, знаходити шляхи їх вирішення, здійснювати самоконтроль, тобто переходити від зовнішнього мотивування до самомотивування. Воно можливе за певних об'єктивних умов, серед яких важливу роль відіграють задоволення первинних потреб працівника, висока культура виробництва, реальне самоуправління. 
Формування ефективної системи мотивації персоналу базується на наступних принципах: простота, доступність, інерційність, циклічність, безперервність. Чим простіша і доступніша система мотивації - тим ефективніше вона працює і більша віддача. Неприпустимо перетин, нагромадження, поглинання, повторення одних і тих же елементів мотивації; інформування всіх співробітників компанії, цілеорієнтованість. Потрібно проводити наради і бесіди 3 керівниками структурних підрозділів, поширювати друковані матеріали, брошури з докладним викладом прийнятої в компанії системи мотивації. Особливо потрібно звертати увагу на «новачків» організації. Важливо донести до свідомості кожного працівника основні цілі розвитку підприємства, взаємоузгодити їх з особистими цілями; готовність долати труднощі з адміністрування, адаптивність. Потрібно постійно підтримувати введену систему мотивації. Наприклад, вводити якісні прикладні розробки, які дозволяють інтегрувати всі потрібні відомості з різних програм, які використовуються в компанії, не ломати, а адаптувати до нового; прозорість системи мотивації, альтернативність, оптимальність. При повній прозорості системи додаткові суми винагород, одержувані кожним співробітником, стають відомі всім. Це призводить до посилення конкуренції між співробітниками, що у свою чергу підсилює мотивацію; справедливість, збалансованість, стабілізація. Суми виплат необхідно заздалегідь планувати і розподіляти між підрозділами і співробітниками; гнучкість, інтегрованість. Потрібно регулярно переглядати систему мотивації, не впроваджувати все розроблене відразу. Можна змінювати стимули, скасовуючи колишні і вводячи нові; відсутність «зрівнялівки», динамічність, пропорційність. Розмір матеріальної винагороди по- винен бути адекватний досягнутим результатам; бюджетування системи мотивації. Необхідно ретельно прорахувати бюджет, передбачити непередбачувані труднощі. На Заході витрати на персонал становлять до $60 \%$ від валового доходу компанії, коли у нашій країні фонд заробітної плати в середньому складає $20-30 \%$ [10].

На нашу думку, крім зазначених принципів, українські виноробні підприємства мають враховувати наступні принципи: інтегрованості матеріальних і нематеріальних методів мотивації. Наприклад, мотивація у вигляді кар'єрного зростання передбачає поєднання як матеріальних методів (підвищення заробітної плати), так і нематеріальних (самовираження працівника); індивідуалізму. При створенні системи мотивації персоналу потрібно враховувати особливості кожного працівника - його вік, психологію, соціальний статус тощо; «доброзичливості». Керівники і їх підлеглі мають взаємоповажати один одного, працівники організації повинні відчувати себе бажаними, а не другорядними особами.

Висновки та перспективи подальших досліджень. Таким чином, важливо наголосити на необхідності застосування інноваційних технологій мотивації персоналу. Розробка нововведень в системі мотивації повинна здійснюватися на основі досліджень існуючої системи стимулювання персоналу, виявлення iii недоліків і можливостей, а також з урахуванням вимог останніх тенденцій і специфіки розвитку підприємства.

Виноробним підприємствам необхідно формувати культуру праці і певну систему цінностей, яка 3 часом може стати фундаментом створення національної моделі управління, здатної забезпечити ефективність самої консервативної галузі економіки.

\section{Література}

1. Щербина В.В. Управление человеческими ресурсами: менеджмент и консультирование: [монографія] / В.В. Щербина. - М.: Независимый институт гражданского общества, 2004. - 520 с.

2. Афонин И.В. Управление развитием предприятия: стратегический менеджмент: [практ. пособие]/ И.В. Афонин. - М.: Изд.-торг. корп. «Дашков и К», 2002. - 380 с.

3. Кларин М.В. Инновации в обучении: метафоры и модели: Анализ зарубежного опыта: [монографія] / М.В. Кларин. - М.: Наука, 2003.-223 с.

4. Бондаренко С.А. Типізація інновацій в забезпеченні балансу інноваційного розвитку виноробних підприємств / С.А. Бондаренко // Економічні інновації. - 2015. - Вип.№ 60, Книга III. - С. 15 - 30.

5. Жежель Ю. В. Управління формуванням грошових потоків підприємств виноробної галузі : автореф. дис. канд. ек. наук : спец. 08.00.04 - «Економіка та управління підприємствами» / Ю. В Жежель. - К., 2010. $-22 \mathrm{c}$.

6. Старцева В. Н. Инновационные технологии управления мотивацией персонала как проблема современного менеджмента / В. Н. Старцева. // Вест. Нижегород. ун-та им. Н. И. Лобачевского. Серия Социальные науки. - 2008. - № 1 (9). - С. 92-97.

7. Мельникова Т.Ф. Исследование лояльности персонала к компании на основе типологической модели мотивации В.И. Герчикова / Т.Ф. Мельникова, С.А. Тарануха, А.В. Мельникова, В.Л. Мельникова // Молодой ученый. - 2015. - №23. - С. 595-599.

8. Долженко Р.А. Системный подход к управлению трудовой мотивацией персонала [Электронный ресурс] / Р.А.Долженко // Предпринимательство. - 2010. - № 8, Вып. 2 (165). - С. 70-75. - Режим доступа : http://www.creativeconomy.ru/articles/10987/

9. Thomas A. Stewart. Intellectual capital. The new wealth of organizations. New York, 2006. 254 p.

10. Биканова О. Мотивація праці як важливий чинник забезпечення ефективного управління персоналом підприємства [Електронний ресурс]. - Режим доступу : http://conf-cv.at.a/forum/53-482-1 


\author{
Бондаренко С.A. \\ кандидат экономических наук, докторант \\ отдел экономического регулирования природопользования \\ Институт проблем рынка и экономико-экологических исследований НАН Украины \\ Французский бульвар, 29, г. Одесса, Украина, 65044 \\ E-mail: lana.bond15@mail.ru \\ Селихов С.В. \\ директор ООО «Селком ЛТД» \\ ул. Фонтанская дорога 12-Г кв.49, г. Одесса, Украина, 65009 \\ E-mail: selser@ukr.net
}

\title{
ФОРМИРОВАНИЕ СИСТЕМЫ МОТИВАЦИИ ПЕРСОНАЛА ВИНОДЕЛЬЧЕСКИХ ПРЕДПРИЯТИЙ НА ОСНОВЕ ИННОВАЦИОННЫХ ТЕХНОЛОГИЙ
}

Для предприятий винодельческой отрасли Украины ключевыми организационными проблемами являются отсутствие современных систем и методов управления, ориентация на подходы, которые были эффрективными в эпоху индустриальной экономики. Система управления интеллектуальным капиталом должна включать обязательное внедрение инновационных технологий мотивации персонала.

Целью данной статьи является выявление современных тенденций и разработка основных аспектов формирования системы мотивации персонала винодельческих предприятий на основе инновационных технологий.

В статье рассматриваются основные аспекты использования инновационных технологий мотивации персонала. Проведен анализ традиционных (эпохи индустриальной экономики) и инновационных (новой эпохи экономики знаний) подходов к мотивации персонала, выделена их актуальность, применительно к специфике винодельческих предприятий. Авторами предложен системный подход к формированию мотивации персонала, выделены основные принципы формирования эффрективной системы мотивации персонала с учетом особенностей винодельческой отрасли. Разработка нововведений в системе мотивации должна осуществляться на основе исследований существующей системы стимулирования персонала, выявление ее недостатков и возможностей, а также с учетом требований последних тенденций и специфики развития предприятия. Совершенствование механизма мотивации персонала, в том числе и управленческого, должно происходить на основе применения мер направленного стимулирования с учетом возможных мотивов конкретных групп персонала предприятия. При этом важным является применение индивидуального подхода к мотивации с дифференциацией персонала не только по категориям, но и согласно этапам трудовой карьеры, с учетом специфики и размера предприятия.

Ключевые слова: мотивация персонала, инновационные технологии мотивации персонала, винодельческие предприятия, система мотивации персонала.

\section{Bondarenko S.}

Ph.D. in Economics, Doctoral candidate

Institute of market problems and economic \& ecological research

of National Academy of Sciences of Ukraine

Frantsuzskiy boulevard, 29, Odessa, Ukraine, 65044

E-mail: lana.bond15@mail.ru

Selikhov S.

Director LLC «Selkom LTD»

Fontanskaya doroga str.,12Г, ap. 49, Odessa, Ukraine, 65009

E-mail: selser@ukr.net

\section{FORMATION OF MOTIVATION WINERIES BASED ON INNOVATIVE TECHNOLOGIESS}

For businesses, the wine industry in Ukraine is a key organizational problems and lack of modern management methods, focus on approaches that are effective in the era of industrial economy. In terms of the knowledge economy the main indicator of the competitiveness of enterprises is its intellectual capital. Intellectual capital management system should include the mandatory introduction of innovative technologies 
motivation. The purpose of this article is to identify current trends and development of key aspects of forming the system of personnel motivation wineries based on innovative technologies. The article examines the main aspects of the use of innovative technologies motivation. Analysis of traditional (industrial economy era) and innovation (modern era of knowledge economy) approaches to motivation, their relevance is highlighted on the specific wineries. The system of motivation describes a set of interrelated activities that encourage individual employee or labor group as a whole to achieve individual and common goals of the company. Motivational system formed as a complex variety of reasons, which in turn determines the standards of conduct. Motivation system is dynamic, its components are constantly changing under the influence of internal and external factors. Proposed a systematic approach to the formation of motivation, highlighted the basic principles of an effective system of motivation allowing for the wine industry. Development of innovations in the system of motivation should be based on existing research staff incentive systems, identification of deficiencies and opportunities, as well as the requirements of the latest trends and specifics of the enterprise. The mechanism of motivation of the personnel, including management, should be based on the application of measures aimed to stimulate consideration of possible grounds certain groups of personnel. It is important to use an individual approach to staff motivation differentiation not only by category but for stage work career-specific and company size.

Wineries should form a work culture and a system of values, which may eventually become the foundation of creating a national model of governance that can ensure the effectiveness of the most conservative industries.

Keywords: staff motivation, innovative technologies motivation, wineries, the system of motivation.

\section{References}

1. Shcherbyna, V. V. (2004). Upravlenye chelovecheskymy resursamy: Menedzhment y konsultyrovanye. M.: Nezavysymыi ynstytut hrazhdanskoho obshchestva.

2. Afonyn Y.V. Upravlenye razvytyem predpryiatyia: stratehycheskyi menedzhment: [prakt. posobye] / Y.V. Afonyn. - M.: Yzd.-torh. korp. «Dashkov y K», 2002. - $380 \mathrm{s.}$

3. Klaryn, M. V. (2003). Ynnovatsyy v obuchenyy: Metaforu y modely: Analyz zarubezhnoho oputa. M.: Nauka.

4. Bondarenko, S. A. (2015). Typizatsiia innovatsii v zabezpechenni balansu innovatsiinoho rozvytku vynorobnykh pidpryiemstv. Ekonomichni Innovatsii, 60, 15-30.

5. Zhezhel, I. V. (2010). Upravlinnia formuvanniam hroshovykh potokiv pidpryiemstv vynorobnoi haluzi. K.

6. Startseva, V. N. (2008, March 4). Ynnovatsyonnue tekhnolohyy upravlenyia motyvatsyei personala kak problema sovre-mennoho menedzhmenta. Vest. Nyzhehorod. Un-ta Ym. N. Y. Lobachevskoho. Seryia Sotsyalnыe Nauky, 1(9), 92-97.

7. Melnykova, T. F., Taranukha, S. A., Melnykova, A. V., \& Melnykova, V. L. (2015). Yssledovanye loialnosty personala k kompanyy na osnove typolohycheskoi mode-ly motyvatsyy V.Y. Herchykova. , Molodoi Uchenui, 23, 595599.

8. Dolzhenko, R. A. (2016, March 3). Systemnui podkhod k upravlenyiu trudovoi motyvatsyei personala. Predprynymatelstvo, 8(2), 70-75.

9. Thomas, S. A. (2006.). Intellectual capital. The new wealth of organizations. New York.

10. Bykanova, O. (n.d.). Motyvatsiia pratsi yak vazhlyvyi chynnyk zabezpechennia efektyvnoho upravlinnia personalom pidpryiemstva. Retrieved from http://conf-cv.at.a/forum/53-482-1

Received 27 March 2016

Approved 14 April 2016

Available in Internet 29.06.2016 